\title{
標準化小委員会だより
}

\section{放射線治療機器班報告 MR班報告}

\section{JIS Z 4705 (医用電子加速装圈一安全) の規格改正の経緯と今後の動向}

医用電子加速装置のJIS規格は，1985年にIEC規格で ある601-2-1“Part 1 総則，Part 2 放射線安全”に準拠し た内容で，JIS Z 4705としてJIS化された。これは準拠 した新規格が放射線安全に関するものであったため, 医用電子加速装置の総合的安全加考えると, 限定さ れた規格であった．医用電子加速装置の統合的安全を 考えたとき，放射線たけけでなく機械的および電気的な 安全も必須であることはいうまでもない。このような 観点から，IECは1984年にIEC 601-2-1 Amendment No.1 を，1990年に同じくNo.2が追加決定された。 また，時 期を同じくして加速装置のコンピュータ制御に関する 安全規定もIEC62C CCO)61 (1990)で追加された。これ らの国際規定の採用動向を踏まえ，JIS Z 4705は“医用 電子加速装置”加“医用電子加速装置一安全”へと規格 名称を一部変更して，1993年に改正された。

1993年のJIS規格では, 本体, 附属書 1, 附属書 2 の 三部構成となっている.JIS Z 4705の改正において委 員会で特に議論となったのが，構成をいかにするかと いう点であった，最終的には，目的および試験方法が 明確であり，JIS規格を利用する者にとって利便性の 高い形式をという結論から，このような三部構成とな った．附属書 1 では“不要又は過㮃な放射線に対する 防護”を，附属書 2 では“不要又は過剩な放射線に対す る防護に関する試験方法”を分離して規定したことが 一つの特徵である．われわれ加速器の使用者がこの規 格を参考にする場合にも，このような分離は有用であ ると思われる。また，試験方法も具体的で現実的なも のになっているといえる.

委員会での議論の中で問題となったもう一つの点 は，医療法施行規則の第30条の 2 との整合性であっ た．第30条の 2 で規定されている診療用高エネルギー
放射線発生装置の障害防止に関わる“(1)発生管の容器 は利用線錐以外の放射線量が利用線錐の放射線量の千 分の一以下になるように遮蔽すること”という条項 と, 附属書 1 の 4.3 項の最大放射線ビーム外の漏れ放 射線(中性子線を除く)の規定值との間には不一致があ る. 医用電子加速装置では加速電子のアライメント調 整上, 電子の加速軌道の延長線上の遮蔽材にピンホー ルを開ける必要がある。この部分は放射線遮蔽上，他 の部分に比して放射線遮蔽能力が劣る．加速装置の性 能を確保するうえで必要なピンホールであり，かつそ の穴の口径が非常に細いということから，この規格で は緩和条件として“0.2\%”を採用している。

この規格は，本格的な医用電子加速装置規格の端緒 となるものである. 最近の加速器においては，コンピ ユータ制御によって放射線発生と機械的動作を連動さ せた新たな機能が登場している。たとえば，ダイナミ ック照射や物理的なくさびフィルタに代わるダイナミ ックくさびフィル夕，そしてマルチリーフコリメータ 等があるが，このような新たなモダリティについては 触れていない。これらのものは，今後より一般化して いく中で規格の中に含まれていくか，あるいは別の規 格として成案を得るであろう．実際，この中には現在 審議が進められているものもある。

品質保証の分野と密接に関連する性能特性について は，すでにIEC 976(1989) とIEC 977（1989）で公表さ れている。これらのドラフトについての審議もすでに 委員会で終了しており，国際一致規格としてわが国に おいても公になる日が近い。それは，JIS規格の形式 がいわゆる翻訳JISを許容するものに改正された現段 階では，公表までの日時はより加速されるであろう。 
くこの規格の対応国際規格〉

IEC 601-2-1 (1981)

Safety of medical electrical equipment Part 2: Particular requirements for the safety of medical electron accelerators in the range $1 \mathrm{MeV}$ to $50 \mathrm{MeV}$

IEC 601-2-1 Amendment No.1 (1984)

Section 3: Electrical and mechanical safety for equip- ment

IEC 601-2-1 Amendment No.2(1990)

Section 1: General

Section 2: Radiation safety for equipment

IEC $62 \mathrm{C}(\mathrm{CO}) 61$ (1990)

Revision of IEC Publication 601-2-1 (1981)

\section{JIS Z 4950 診断用磁気共鳴装置一図記号および標識制定について}

診断用磁気共鳴装置(厚生省から出された「医療用具 の一般名称」薬発1008号によると「磁気共鳴画像診断装 置」になった)は，電離放射線を使用しないため，安全 な画像診断装置であると思われている，しかし，強力 な磁場および高周波を使用していることにより，これ らに対する注意や対策をしないと危険なこともあり， 場合によっては事故にもなりかねない。

このため，MR検查室に入室する際，磁気や高周波 に対する注意を喚起する目的で，入り口の屝や壁など に揭示する標識(いくつかの図記号を組み合わせたも の)を作成した。

JIS化に先立ち, 日本放射線機器工業会のMR標準化 委員会 (技術学会からも委員を派遣)で審議を行い, 平 成 2 年に工業会規格として制定された。この工業会規 格を基に，IEC規格や他の国の規格を参考にして，日 本放射線機器工業会委託で原案が審議された。

また，既存のものがない図記号については，新たに デザインして平成 7 年にJIS規格として発行された。

内容は次の三つのグループに分類し，12の図記号を 規定した.

1) 人の生命, 障害に対する安全.

2) 財産価值，情報価值を持つものに対する保護.

3) MR装置そのものの障害, 異常動作の防止.

図記号 1 : 強磁場注意

強磁場に対する注意記号

図記号 2 : 高周波使用

撮像時に高周波が使用されていること の注意記号.

四記号 3 ：ペースメーカ装着者の入室禁止

生命維持に必要な電子機器の装着者に 対し，強力な磁場または高周波の影響に よる障害を防止するため，MR検査室への 入室を禁止する。
図記号 4 ：体内に磁性金属のある人の入室禁止

体内金属が磁性か非磁性か確認が困難 であるため禁止としたが，すべてという ことではなく，「医師の許可なく」の文言 を入れた。また，図にはいろいろな案が 出されたが最も危険と思われる脳動脈ク リップを図案化した。

図記号 5 ：金属磁性体装身具の持ち込み禁止

装身具としてMR検査室に持ち込まれる 可能性のあるもので磁力に吸引された り，高周波によって発熱したり，画像に 悪影響を与える恐れのあるものの持ち込 みを禁止する。

ヘアピンと安全ピンを図案化した。

図記号 6 ：鉄製小物持ち込み禁止

身の回り品で磁力による吸引力で飛ば される恐れのあるものの持ち込みを禁止 する。

IECでは「鍵」を図案化しているが，JIS では先が尖っていて危険度のより高い筆 記具およびはさみを図案化した。

図記号 7 : 鉄製移送用機器・鉄製補助用具持ち込み 禁止

磁力で吸引される危険のあるものとし て，鉄製ストレッチャ，車椅子およびそ れらに付随する器具の持ち込みを禁止す る.

図記号 8 ：鉄製容器持ち込み禁止

磁力で吸引されることによって衝突など の危険を持つものの持ち込みを禁止する.

代表として消火器を図案化した。

図記号 9：精密機器・電子機器持ち込み禁止

おもに静磁場の影響で機能を停止した り，故障を引き起こすおそれのある精密 機器, 電子機器の持ち込みを禁止する. 